\title{
Copepod grazing selection and particle discrimination on the basis of PSP toxin content
}

\author{
Gregory J. Teegarden*
}

Graduate School of Oceanography, University of Rhode Island, Narragansett, Rhode Island 02882, USA

\begin{abstract}
Omnivorous copepods are capable of discriminatory feeding using mechano- and chemosensory mechanisms. The presence of phycotoxins in phytoplankton often results in reduced consumption of such potential prey by copepods, though it has not been clear if this is the result of discriminatory feeding by either tactile (mechanosensory) or chemosensory recognition of toxic prey, or perhaps a physiological response to ingested neurotoxic compounds. In this study, experiments were performed to determine whether 3 species of marine copepods (Acartia tonsa, Centropages hamatus, and Eurytemora herdmani) that commonly co-occur with toxic Alexandrium spp. dinoflagellates were capable of discriminating between cultured Alexandrium spp. strains on the basis of paralytic shellfish poisoning (PSP) toxin content, i.e. by chemosensory means, using live fluorescently labeled cells. Additional experiments investigated whether toxic cells in mixtures with non-toxic alternate species of dinoflagellates affected either prey selection or total carbon consumption rates of copepods, and whether daily carbon rations could be maintained on both toxic and non-toxic Alexandrium spp. monoculture diets. Results indicated that all 3 copepod species could discriminate between toxic and nontoxic Alexandrium spp. cells by chemosensory means, suggesting that selective behavior, rather than physiological effects, governs the grazing response of copepods exposed to toxic prey. Prey selection in mixtures of several dinoflagellate species depended on whether the Alexandrium spp. cells present were toxic or non-toxic. C. hamatus and E. herdmani (but not A. tonsa) maintained daily carbon rations despite the presence of toxic Alexandrium spp., chiefly through increased consumption of alternate prey. For $A$. tonsa and $C$. hamatus, carbon rations were not equivalent between toxic and non-toxic Alexandrium spp. monoculture diets, indicating strong aversions to PSP toxins, and the potential for physiological effects when no other food is available. In all experiments feeding behavior varied among copepod species, suggesting that grazing pressure on toxic Alexandrium spp. is not uniform throughout the zooplankton community. The grazer-deterrent effects observed have implications for the function of PSP toxins.
\end{abstract}

KEY WORDS: Alexandrium · Copepod · Grazing behavior · PSP toxins

\section{INTRODUCTION}

Dinoflagellates of the genus Alexandrium often produce neurotoxic compounds commonly known as paralytic shellfish poisoning (PSP) toxins. A tamarense (Lebour) Balech and $A$. fundyense Balech occur and may proliferate in the coastal waters of northeastern North America. Toxins produced by these species can contaminate filter-feeding shellfish, resulting in eco-

•E-mail: gregt@gsosun1.gso.uri.edu nomic losses and a threat to public health (Shumway et al. 1988). Toxigenic Alexandrium spp. can also adversely affect other components of the marine food web, including finfish and marine mammals, probably via a zooplankton vector (White 1979, 1980, 1981, Geraci et al. 1989). Grazing by zooplankton and filterfeeding shellfish may also serve to moderate Alexandrium spp. bloom formation (Turner \& Anderson 1983, Watras et al. 1985). In general, grazing (or the lack thereof) may be a principal biological mechanism by which harmful algal blooms are either terminated or allowed to persist (Smayda 1992). Furthermore a large 
proportion of the total toxins produced in a bloom may pass through grazers, with the potential to spread throughout the food web. It is therefore important to understand the mechanisms governing the response of grazers to harmful algal blooms, so that we can understand both the reasons for bloom formation and the potential impact on food webs.

The effect of toxigenic phytoplankton on the feeding behavior of omnivorous zooplankton can vary greatly among zooplankton species (see Turner \& Tester 1997 and references therein). In experiments with Alexandrium spp., some studies have reported a reduced grazing response of zooplankton to toxic prey cell types compared with non-toxic alternatives (Ives 1985. 1987, Turriff et al. 1995), although reasonably high ingestion rates of toxic Alexandrium spp. have been observed with no apparent physiological effects (Teegarden \& Cembella 1996). The mechanism of potentially reduced zooplankton grazing rates on toxic Alexandrium spp. has been the subject of some investigation (Ives 1987, Turriff et al. 1995, Teegarden \& Cembella 1996). Earlier evidence supported a physiological basis for reduction of copepod grazing rates (Ives 1987; for other species see Huntley et al. 1986, Uye \& Takamatsu 1990), whereas later studies have concluded that discriminatory feeding selection is important in the grazing response of omnivorous copepods (Turriff et al. 1995, Teegarden \& Cembella 1996). Nevertheless it has been unclear whether the postulated selective grazing can be attributed to the actual toxin content of the cells, or to other factors affecting palatability, or indeed whether grazers may have to sample toxic cells and learn to recognize them by tactile means to avoid subsequent ingestion (Sykes 1991).

This study was designed to determine whether PSP toxins have a role in the selective grazing response of 3 coastal copepods that commonly occur along with Alexandrium spp. in the estuaries and embayments of the Gulf of Maine. Acartia tonsa Dana, Centropages hamatus Lilljeborg, and Eurytemora herdmani Thompson \& Scott were tested for the ability to distinguish between toxic and non-toxic clonal cultures of Alexandrium spp. that are virtually identical in other respects, in mixtures containing equal numbers of each clone. Additional experiments investigated the feeding response of these copepods to mixtures of several species of dinoflagellates including either toxic or nontoxic Alexandrium spp., to determine if both prey cell selection and overall carbon consumption rates differed between treatments as a result of the presence of toxic prey. Finally each copepod species was tested in grazing trials with monocultures of toxic or non-toxic Alexandrium spp., to determine whether carbon consumption rates could be maintained when only 1 prey type was available.

\section{MATERIALS AND METHODS}

Phytoplankton culture. Three clones of Alexandrium spp. were used in various experiments. $A$. tamarense (Lebour) Balech clone CCMP 115 (= PLY 173) was obtained from the Guillard/Provasoli Center for the Culture of Marine Phytoplankton, Boothbay Harbor, Maine. A. tamarense clone GTCN 16 and A. fundyense clone GTCA 28 were provided by the laboratory of Dr Donald M. Anderson, Woods Hole Oceanographic Institution. The CCMP 115 clone was identified as non-toxic, while GTCN 16 has been reported as a low-toxicity clone and GTCA 28 as a moderate- to high-toxicity clone (D. M. Anderson pers. comm.). Samples from experiments were analyzed by high performance liquid chromatography with fluorescence detection (HPLC-FD; see Teegarden \& Cembella 1996 for details) under the direction of Dr Allan Cembella at the Institute for Marine Biosciences, NRC, Halifax, Nova Scotia. HPLC-FD analysis confirmed CCMP 115 samples to be below detection limits for PSP toxins. GTCN 16 samples also tested below detection limits, such that the clonal cultures used in these experiments may be considered functionally non-toxic. GTCA 28 samples tested moderately toxic as expected (Table 1). There was some variation in toxicity of the $A$. fundyense GTCA 28 culture over time, but toxicity remained within the normal range for this clone. Consistent experimental results (presented below) suggest that such toxin variation had no effect on experimental outcomes.

Additional species of dinoflagellates used in mixed species experiments were Lingulodinium polyedrum (Stein) Dodge clone CCMP 407 (Guillard/Provasoli CCMP), and Gonyaulax of cochlea Meunier clone B199J (= CCMP 1592) and Prorocentrum micans Ehrenberg clone C 26 from the laboratory of Dr P. E. Hargraves, Graduate School of Oceanography, University of Rhode Island. None of these dinoflagellate clones produce known toxins.

All of the aforementioned phytoplankton clones were cultured in an environmental room at $18^{\circ} \mathrm{C}$, with a $14 \mathrm{~h}: 10 \mathrm{~h}$ light:dark cycle using cool white fluorescent lamps. Culture medium was prepared from autoclaved $0.45 \mu \mathrm{m}$ filtered Narragansett Bay water, approx. 28 to 30 PSU, enriched with f/2 - Si (Guillard 1975). Stock cultures were used to inoculate $8 \mathrm{I}$ bottles every $2 \mathrm{wk}$ to provide quantities of exponentially growing phytoplankton for experiments; only exponential phase cultures were used.

Zooplankton collection. Zooplankton were collected from the Damariscotta River estuary in Walpole, Maine, an area that has experienced blooms of toxic and non-toxic Alexandrium spp. in recent years (Yentsch et al. 1978, Maine Dept Marine Resources 
Table 1. Toxicity of Alexandrium spp. clones used in grazing experiments with the 3 species of copepods. The first column indicates copepod species, followed by the type of experiment performed, the Alexandrium spp. clone tested, and the toxicity measured for that clone, in pg saxitoxin equivalents (STXeq) per cell

\begin{tabular}{|c|c|c|}
\hline $\begin{array}{l}\text { Copepod sp. } \\
\text { Experiment }\end{array}$ & $\begin{array}{l}\text { Alexandrium } \\
\text { clone }\end{array}$ & $\begin{array}{c}\text { Toxicity } \\
\left(\text { pgSTXeq cell }{ }^{-1}\right)\end{array}$ \\
\hline \multicolumn{3}{|l|}{ Acartia tonsa } \\
\hline \multirow[t]{3}{*}{ Selection } & GTCA 28 & 19.8 \\
\hline & CCMP 115 & 0.0 \\
\hline & GTCN 16 & 0.0 \\
\hline \multirow[t]{2}{*}{ Mixed species } & GTCA 28 & 20.7 \\
\hline & CCMP 115 & 0.0 \\
\hline \multirow[t]{2}{*}{ Carbon ingestion } & GTCA 28 & 25.0 \\
\hline & CCMP 115 & 0.0 \\
\hline \multicolumn{3}{|c|}{ Eurytemora herdmani } \\
\hline \multirow[t]{3}{*}{ Selection } & GTCA 28 & 31.0 \\
\hline & CCMP 115 & 0.0 \\
\hline & GTCN 16 & 0.0 \\
\hline \multirow[t]{2}{*}{ Mixed species } & GTCA 28 & 20.7 \\
\hline & CCMP 115 & 0.0 \\
\hline \multirow[t]{2}{*}{ Carbon ingestion } & GTCA 28 & 15.4 \\
\hline & CCMP 115 & 0.0 \\
\hline \multicolumn{3}{|c|}{ Centropages hamatus } \\
\hline \multirow[t]{2}{*}{ Selection } & GTCA 28 & 31.0 \\
\hline & CCMP 115 & 0.0 \\
\hline \multirow[t]{2}{*}{ Mixed species } & GTCA 28 & 17.5 \\
\hline & CCMP 115 & 0.0 \\
\hline \multirow[t]{2}{*}{ Carbon ingestion } & GTCA 28 & 12.7 \\
\hline & CCMP 115 & 0.0 \\
\hline
\end{tabular}

PSP monitoring reports; L. Bean pers. comm.). A $150 \mu \mathrm{m}$ mesh net was suspended in the tidal flow, allowing gentle collection of larger zooplankton. Adult females of the copepod species Acartia tonsa, Centropages hamatus, and Eurytemora herdmani were sorted out and used to establish cultures in laboratory facilities at the University of Rhode Island. Copepods were kept in multiple 221 containers with aeration and regular water changes, and fed a diet of mixed dinoflagellate species (Heterocapsa triquetra clone HT984 and Gymnodinium sanguineum clone B4). A. tonsa was maintained at $19^{\circ} \mathrm{C}$, and C. hamatus and E. herdmani were maintained at $17^{\circ} \mathrm{C}$, with $14 \mathrm{~h}: 10 \mathrm{~h}$ light:dark cycles. All 3 species exhibited vigorous growth and reproduction in culture, and, although cultures could be maintained indefinitely, they were occasionally augmented with freshly collected zooplankton.

Alexandrium spp. selection experiments. Staining of dinoflagellates: The Alexandrium spp. clones used in experiments reported here are virtually identical in size and shape, carbon and nitrogen per cell, etc. $A$. tamarense and $A$. fundyense are separated on the basis of a pore on the 1' apical plate of $A$. tamarense which $A$. fundyense lacks (Balech 1990). The 2 species can be crossed in sexual reproduction, and are considered by many to be conspecific (A. Cembella pers. comm.). Mixtures of toxic $A$. fundyense and non-toxic A. tamarense were used to test copepods for the ability to discriminate between particles on the basis of PSP toxin content. In order to be able to distinguish between the 2 virtually identical cell types in a mixture, one of the cell types was labeled with a live fluorescent vital stain, Cell Tracker ${ }^{\otimes}$ Blue CMAC (7-amino 4-chloromethylcoumarin, Molecular Probes Inc.), which fluoresces blue when excited by UV light at $354 \mathrm{~nm}$. Chambers constructed for the labeling procedures consisted of polycarbonate screw top bottles fitted with a $5 \mu \mathrm{m}$ mesh bottom and a slow drip flat funnel supporting the mesh, with controllable outflow. Exponentially growing cells were stained with the label at a final concentration of $5 \mu \mathrm{M}$ in filtered seawater, and incubated at $18^{\circ} \mathrm{C}$ for $4 \mathrm{~h}$. The cells were then gently rinsed free of excess label by transferring the solution to the chamber, reducing the solution volume and replacing with filtered seawater, repeating several times. Cells were allowed to recover from the treatment overnight at $18^{\circ} \mathrm{C}$, and checked for label efficacy with epifluorescence microscopy and for cell viability. Only cultures that had $100 \%$ of sampled cells labeled and viable were used in experiments. As a precautionary control measure, unlabeled cells were subjected to the same handling procedure without CMAC. Preliminary experiments, prior to grazing trials, tested cells for label retention through cell divisions, and samples maintained visible label in $100 \%$ of the cells through $3 \mathrm{~d}$ (division rates approx. $0.25 \mathrm{~d}^{-1}$ ). The label does not appear to leak from cells, and any released through disruption (e.g. grazing) should not affect unlabeled cells, due to the relatively high concentrations needed to effectually label Alexandrium spp. dinoflagellates. Additional preliminary experiments confirmed that the presence of label did not affect palatability of cells to the copepods tested.

Experimental design: The 3 copepod species were tested for the ability to discriminate between toxic Alexandrium fundyense GTCA 28 and non-toxic $A$. tamarense CCMP 115 in mixtures by labeling one clone and mixing with equal numbers of the other (subjected to equal treatment without label). As an added control, 2 treatments were run simultaneously for each grazing trial; one treatment with labeled toxic A. fundyense GTCA 28 mixed with unlabeled nontoxic A. tamarense CCMP 115, and another treatment with unlabeled GTCA 28 mixed with labeled CCMP 115. Although preliminary experiments showed no effect of label on palatability, such treatments should guard against any possible discrepancies. I also tested for differences in palatability between non-toxic clones 
of A. tamarense on 2 occasions, by feeding Acartia tonsa and Eurytemora herdmani mixtures of $A$. tamarense GTCN 16 (functionally non-toxic) and $A$. tamarense CCMP 115 (non-toxic).

Grazing trials were performed the day after cultures of Alexandrium spp. were labeled. Cell concentrations were determined with a Coulter Counter model $Z M$, and cultures were mixed to give experimental solutions at a concentration of 200 cells $\mathrm{ml}^{-1}$ of each type (400 cells $\mathrm{ml}^{-1}$ total). These concentrations allow acceptable confidence in post-experimental visual cell counts, and also ensure that the potential for selection is not affected by possible food limitation which might constrain grazers to consume less palatable prey. Adult females of the copepod species being tested were sorted from cultures and, without delay, triplicate experimental containers were prepared for each treatment containing 10 copepods in $280 \mathrm{ml}$ of experimental Alexandrium spp. cell mixtures. Replicate control containers and initial containers without animals were prepared at the same time. Control and experimental containers were placed on a grazing wheel rotating at $1 \mathrm{rpm}$ in a temperature controlled water bath, at $19^{\circ} \mathrm{C}$ for Acartia tonsa, or $17^{\circ} \mathrm{C}$ for Centropages hamatus and Eurytemora herdmani. Experiments were run for $24 \mathrm{~h}$ on a $14 \mathrm{~h}: 10 \mathrm{~h}$ light:dark cycle. Initial container samples were processed immediately at the start of an experiment. At the end of an experiment, copepods were removed and examined for physiological condition. Replicate $2 \mathrm{ml}$ subsamples of control and experimental cell mixtures were gently filtered down onto gridded membranes (Millipore RA), which were cleared with a drop of immersion oil, and cell counts were made using an Olympus microscope with epifluorescence illumination. The counting procedure took generally less than $6 \mathrm{~h}$, but additional subsamples were preserved with $1.25 \%$ formaldehyde as a precaution, and counted if necessary (formaldehyde does not affect the fluorescent label). Algal growth rates in control containers and copepod grazing rates in experimental containers were calculated from the equations of Frost (1972) and analyzed with factorial ANOVA

Mixed dinoflagellate species grazing experiments. To determine whether the presence or absence of toxin in Alexandrium spp. affected the grazing response of the 3 copepod species (selective preferences and total carbon consumption rates) when multiple dinoflagellate species were available, additional grazing trials were conducted using mixtures of Alexandrium spp. and 3 alternate non-toxic dinoflagellate species. Mixtures contained Lingulodinium polyedrum clone CCMP 407 ( 29 um diameter), Gonyaulax cochlea clone B199J ( 24 um diameter), Prorocentrum micans clone C 26 ( $27 \mu \mathrm{m}$ diameter), and either A. tamarense CCMP 115 (non-toxic) or A. fundyense GTCA 28 (toxic; both $\sim 27 \mu \mathrm{m}$ diameter). Cell mixtures were prepared at approx. $300 \mu \mathrm{g} \mathrm{C} \mathrm{I}^{-1}$ of each type (1200 $\mu \mathrm{g} \mathrm{C} \mathrm{I}^{-1}$ total). As before, adult females of the copepod species being tested were sorted out from cultures and immediately placed into $280 \mathrm{ml}$ experimental containers, 20 copepods each in triplicate containers for each of the 2 treatments (mixtures containing toxic $A$. fundyense GTCA 28, and mixtures containing non-toxic A. tamarense CCMP 115). Control containers with no grazers were prepared at the same time, and then incubated with experimental containers on a grazing wheel in a temperature controlled water bath for $24 \mathrm{~h}$. Initial samples were preserved immediately with Lugol's iodine solution. At the end of the incubation, copepods were removed and examined for physiological condition, and dinoflagellate mixtures were preserved with Lugol's solution. Replicate subsamples were then counted for all dinoflagellate species using a Sedgwick-Rafter chamber with phase contrast microscopy. Algal growth rates and copepod grazing rates were calculated with the Frost (1972) equations, and results analyzed by ANOVA with LSD post-hoc testing using $\mathrm{SAS}^{\circledast}$ (Cody \& Smith 1991).

Monoculture grazing experiments. To determine whether equivalent carbon consumption rates could be maintained with either toxic or non-toxic cells as the sole food source, grazing trials were conducted with the 3 species of copepods using monocultures of either toxic Alexandrium fundyense GTCA 28 or non-toxic $A$. tamarense CCMP 115. Alexandrium spp. cultures were harvested and counted with a Coulter ${ }^{\circledR}$ Counter Multisizer, and diluted in filtered seawater to 500 cells $\mathrm{ml}^{-1}$ (approx. $1000 \mu \mathrm{g} \mathrm{C} \mathrm{l}^{-1}$ ). Triplicate experimental containers were prepared for each treatment, with 20 adult females in $280 \mathrm{ml}$ in each container, along with control and initial containers. Triplicate initial samples of 20 adult female copepods were also taken and prepared for $\mathrm{CHN}$ analysis. Experimental and control containers were incubated as before on the grazing wheel in a temperature controlled water bath for $24 \mathrm{~h}$; initial containers were counted immediately with the Multisizer. At the end of an experiment copepods were removed and examined for physiological condition, then placed into tin boats and dried for CHN analysis. Cell concentrations in experimental and con trol containers were determined with the Multisizer (using volume \% mode to minimize artifacts), and grazing rates were calculated by the Frost (1972) equations and analyzed with 2-way ANOVA. Subsamples of algal cultures used were collected on precombusted glass fiber filters $\left(10^{5}\right.$ cells filter $\left.{ }^{-1}\right)$, and copepod and algal samples were analyzed with a Carlo Erba CHN analyzer 


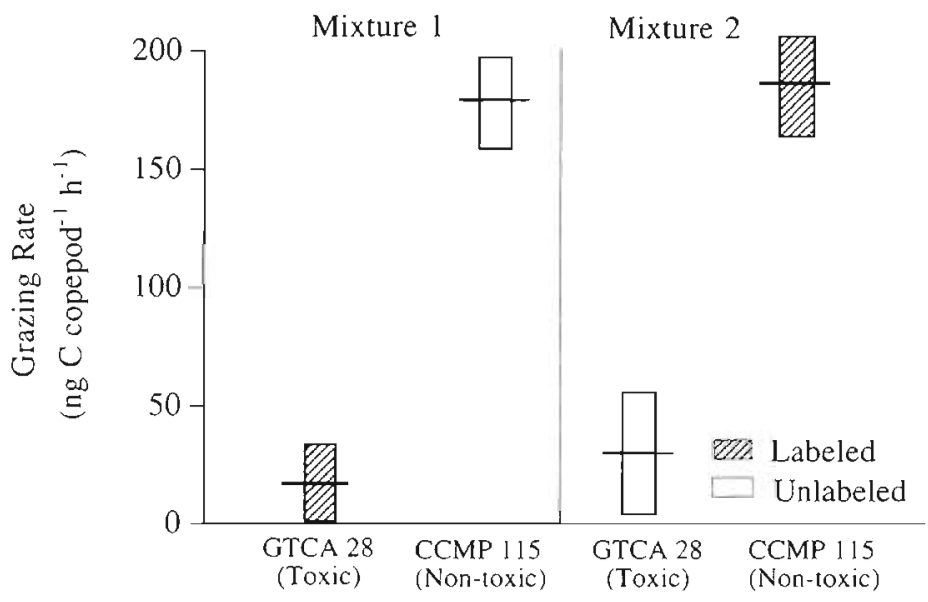

Fig. 1. Acartia tonsa grazing rates on Alexandrium spp. dinoflagellates in mixtures of toxic and non-toxic cells. Central bars denote mean rates, and boxes indicate 1 standard deviation. Mixture 1 contained fluorescently labeled toxic A. fundyense GTCA 28 and unlabeled nontoxic A. tamarense CCMP 115 in equal numbers; in mixture 2 the label sequence was reversed. In either mixture, non-toxic Alexandrium spp. cells were consumed at significantly higher rates $(p<0.001)$ than toxic cells, which were avoided despite their physical similarity

\section{RESULTS}

\section{Alexandrium spp. selection experiments}

Acartia tonsa and Centropages hamatus revealed a striking ability to distinguish between toxic and nontoxic Alexandrium spp. cultures in mixtures, whereas Eurytemora herdmani was capable of distinguishing between cell types, but was less likely to do so. When Acartia tonsa females grazed in mixtures of toxic GTCA 28 (A. fundyense) and non-toxic CCMP 115 (A. tamarense), regardless of the presence or absence of fluorescent label, the non-toxic Alexandrium clone was always consumed at a much higher rate (Fig. 1). C. hamatus also grazed non-toxic Alexandrium clone CCMP 115 in preference to toxic GTCA 28 (Fig. 2), but consumed the toxic clone at a relatively higher rate than $A$. tonsa. The difference in $C$. hamatus grazing rates between the 2 clones of Alexandrium spp. in mixtures was highly significant $(\mathrm{p}<0.001)$, but only 3 - to 4 fold, whereas Acartia tonsa exhibited an 8 - to 10 -fold difference between grazing rates on the 2 Alexandrium spp. clones $(p<0.001)$.

When first tested, Eurytemora herdmani did not exhibit any significant differences between grazing rates on either the toxic or non-toxic Alexandrium spp. clones, in either of the 2 treatment mixtures (Fig. 3a). Slight (non- significant, $p=0.07$ ) preferences for non-toxic A. tamarense CCMP 115 encouraged a replication of the experiment. When the same experiment was performed $1 \mathrm{wk}$ later, E. herdmani displayed a significant preference $(\mathrm{p}<$ 0.001 ) in both treatments for the non-toxic CCMP 115 A. tamarense clone over the toxic GTCA 28 A. fundyense clone (Fig. 3b), although the average difference in grazing rates was not as great as those exhibited by Acartia tonsa or Centropages hamatus. In experiments with all 3 copepod species, some toxic cells were ingested, though the extent to which toxic cells contributed to the diet varied among species of copepod. In all the experiments, copepods examined after grazing trials were in good condition, did not show signs of physiological impairment, and had food in the guts.

Acartia tonsa and Eurytemora herdmani were also tested with Alexandrium tamarense clones that were both functionally non-toxic, CCMP 115 and GTCN 16 (Fig. 4). Grazing trials with both copepod species revealed that in no cases were grazing rates significantly different between the $A$. tamarense clones in mixtures, indicating a lack of selective preference.

\section{Mixed dinoflagellate species grazing experiments}

All 3 copepod species exhibited significantly different grazing responses in mixtures of dinoflagellate species depending on the presence or absence of toxin

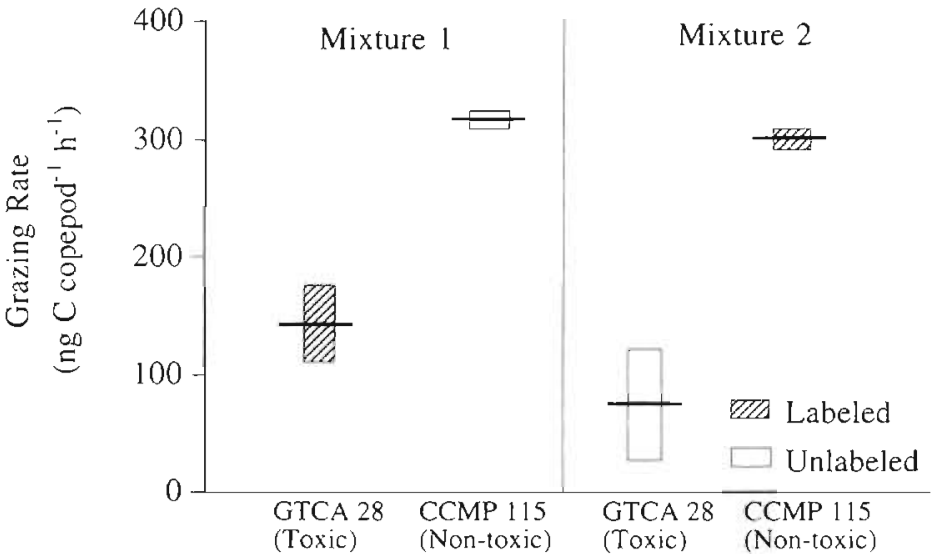

Fig. 2. Centropages hamatus grazing rates on Alexandrium spp dinoflagellates in mixtures of toxic and non-toxic cells. Central bars denote mean rates, and boxes indicate 1 standard deviation. Non-toxic A. tamarense cells were consumed at significantly higher rates than toxic $A$. fundyense cells ( $\mathrm{p}<0.001$ ). Nevertheless toxic cells constituted up to a third of the diet 

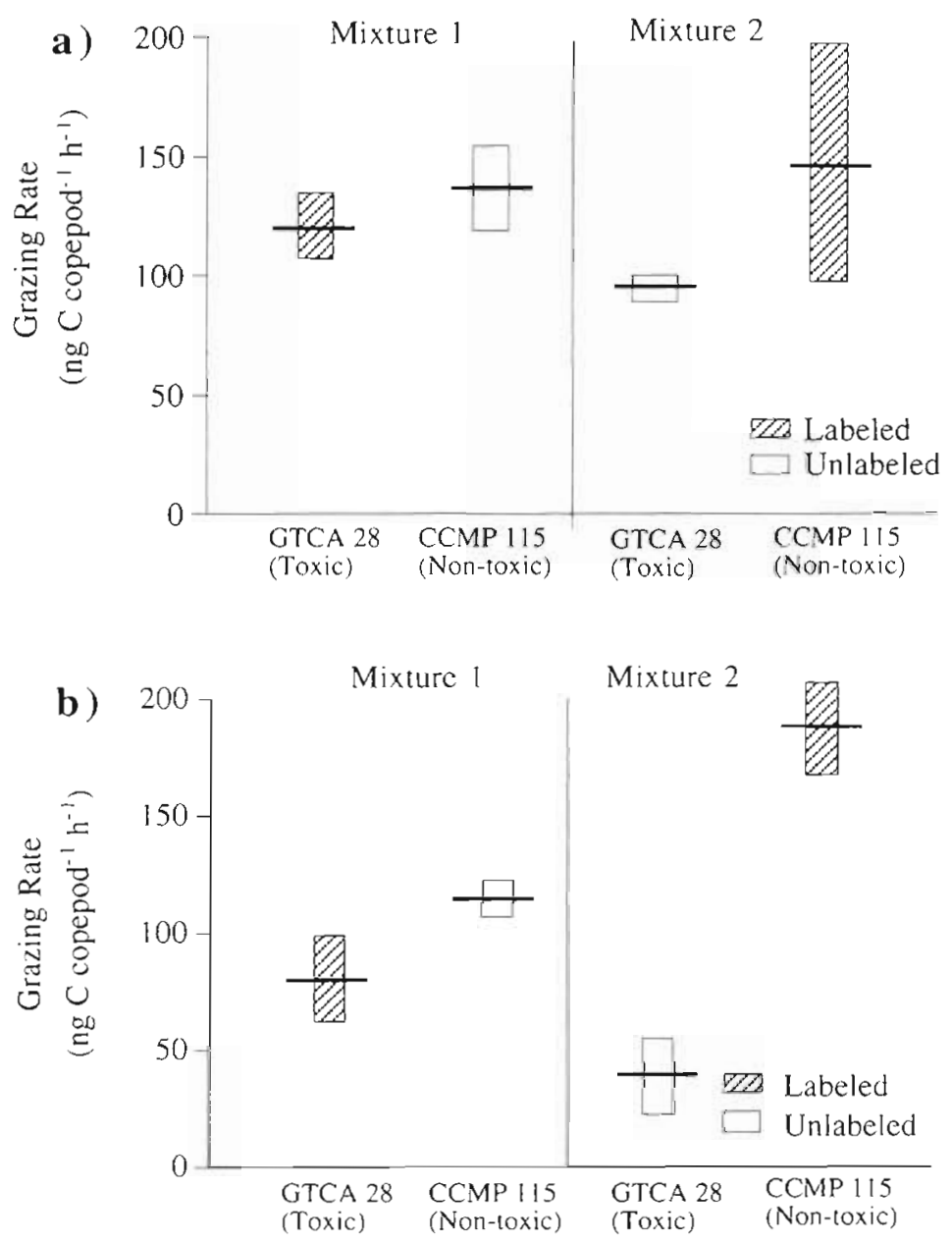

Fig. 3. Eurytemora herdmani grazing rates on Alexandrium spp. dinoflagellates in mixtures of toxic and non-toxic cells. Central bars denote mean rates, and boxes indicate 1 standard deviation. (a) The first trial resulted in no significant differences between grazing rates on toxic and non-toxic cells in a mixture $(\mathrm{p}=0.073)$. (b) In the second trial, $E$. herdmani demonstrated significantly higher grazing rates on non-toxic A. tamarense CCMP 115 over toxic A. fundyense GTCA 28 , though variability was high and the 2 mixture treatments were not identical (see 'Discussion')

in the Alexandrium spp. clone included in the mixture. Only 1 species (Acartia tonsa) had a significantly lower total carbon consumption rate as a result. In mixtures containing non-toxic A. tamarense CCMP 115, A. tonsa consumed this dinoflagellate clone at a significantly higher rate (100 ng $C$ copepod ${ }^{-1} \mathrm{~h}^{-1}, \mathrm{p}<0.01$ ) than any other dinoflagellate species (Fig. 5a). Prorocentrum micans was consumed at significantly lower $(p<0.01)$ rates than either Gonyaulax cochlea or Lingulodinium polyedrum, which were consumed at moderate rates of 60 to $70 \mathrm{ng} C$ copepod ${ }^{-1} \mathrm{~h}^{-1}$. When presented with a mixture containing toxic $A$. fundyense GTCA 28 (Fig. 5b), A. tonsa grazed this clone at $16 \mathrm{ng} C$ copepod $^{-1} \mathrm{~h}^{-1}$, similar to the rate on $P$. micans, and more than 6 -fold lower than the rate on non-toxic A. tamarense CCMP 115 from the previous treatment. L. polyedrum and $G$. cochlea were grazed at significantly higher rates than the 2 other dinoflagellate species, $L$, polyedrum being grazed at the highest rate $(p<0.01)$. A. tamarense CCMP 115 constituted a large proportion $(39 \%)$ of the total carbon intake of $A$. tonsa in the first treatment, and the substitution of toxic $A$. fundyense GTCA 28 in the second treatment induced a shift in dependence for carbon ration to $L$. polyedrum (54\%). Nevertheless, A. tonsa had a lower total carbon intake rate in the second treatment compared with the first treatment $\left(4.15\right.$ and $6.23 \mu g_{\text {copepod }}{ }^{-1}$ $\mathrm{d}^{-1}$, respectively, $\mathrm{p}=0.02$ ).

Centropages hamatus also demonstrated a significant $(p<0.01)$ preference for non-toxic Alexandrium tamarense CCMP 115 over all other dinoflagellate species in mixed species experiments (Fig. 6a), obtaining half of the measured daily carbon ration from that clone (220 ng $\mathrm{C}$ copepod $^{-1} \mathrm{~h}^{-1}$ ); Lingulodinium polyedrum and Gonyaulax cochlea were grazed at similar lower rates $(-100 \mathrm{ng} C$ copepod $\left.^{-1} \mathrm{~h}^{-1}\right)$, and Prorocentrum micans was grazed at the lowest rate $(-30 \mathrm{ng} \mathrm{C}$ cope$\operatorname{pod}^{-1} \mathrm{~h}^{-1}$ ). Substitution of toxic $A$. fundyense GTCA 28 in the second treatment resulted in a great reduction in the carbon consumption of Alexandrium spp. by C. hamatus (Fig. 6b). Grazing rates on $G$. cochlea and $L$. polyedrum increased relative to the first treatment, and were equivalent at about $140 \mathrm{ng} C$ copepod $^{-1} \mathrm{~h}^{-1}$, whereas toxic $A$. fundyense GTCA 28 was grazed at a significantly lower rate, and $P$. micans at the lowest rate $(\mathrm{p}<0.01)$. Increased consumption of $L$. polyedrum and $G$. cochlea in the second treatment relative to the first treatment allowed $C$. hamatus to maintain equivalent daily carbon rations in both treatments $\left(\sim 10.5 \mu \mathrm{g}\right.$ copepod $\left.\mathrm{d}^{-1} \mathrm{~d}^{-1}\right)$, despite the difference in consumption of Alexandrium spp.

As with the other copepod species, Eurytemora herdmani fed upon non-toxic Alexandrium tamarense CCMP 115 at a significantly higher $(p<0.01$ ) rate, $50 \mathrm{ng} \mathrm{C}$ copepod ${ }^{-1} \mathrm{~h}^{-1}$, than any other species of dinoflagellate in the first treatment, and consumed Prorocentrum micans at a significantly lower rate $(p<$ 0.01, Fig. 7a). Gonyaulax cochlea and Lingulodinium polyedrum were consumed at similar, intermediate rates. In the second treatment containing toxic $A$. fundyense GTCA 28, the grazing rate on that Alexandrium clone was reduced 3 -fold compared to $A$. 
tamarense in the first treatment (Fig. 7b). The grazing rate on $L$. polyedrum nearly doubled in the second treatment, and was significantly higher $(p<0.01)$ than grazing rates on any other dinoflagellate species; grazing rates on $G$. cochlea, A. fundyense and $P$. micans were not significantly different. The means of total daily carbon intake of $E$. herdmani in the non-toxic and toxic treatments (6.5 $\mathrm{\mu g}$ copepod ${ }^{-1} \mathrm{~d}^{-1}$ and $5.4 \mathrm{\mu g}$ copepod ${ }^{-1}$ $\mathrm{d}^{-1}$, respectively) were not significantly different $(p=0.19)$, suggesting that $E$. herdmani can obtain equivalent carbon rations in the presence or absence of toxic prey.

\section{Monoculture grazing experiments}

Acartia tonsa and Centropages hamatus consumed significantly different total carbon rations when grazing monocultures of nontoxic Alexandrium tamarense CCMP 115 or toxic A. fundyense GTCA 28, but Eurytemora herdmani did not exhibit significantly different grazing rates or total carbon rations between the 2 Alexandrium spp. clone monoculture diets $(\mathrm{p}=0.18$, Fig. 8). A. tonsa consumed an average of $196 \%$ of their mean body carbon $\mathrm{d}^{-1}$ when grazing a monoclonal culture of non-toxic A. tamarense CCMP 115, and showed a significant increase in carbon biomass $(p<0.01)$ over initial copepod samples of $18 \%$ (Table 2). When grazing toxic $A$. fundyense GTCA 28 , A. tonsa only consumed an average of $61 \%$ of their body carbon $\mathrm{d}^{-1}$, and lost $28 \%(\mathrm{p}<0.01)$ of the body carbon contained in initial copepod samples (Table 2), indicating starvation that should result in mortality if maintained over longer periods. Copepods from this treatment examined after experiments were clearly impaired, and were incapable of directed swimming or pipette avoidance, but did appear to have some food in the guts. Copepods from the non-toxic monoculture treatment were healthy, active, and had food in the guts.

Centropages hamatus consumed an average of $47 \%$ of their mean body carbon $\mathrm{d}^{-1}$ when grazing non-toxic Alexandrium tamarense CCMP 115 , and showed a significant ( $\mathrm{p}<0.05$ ) increase in body carbon of $24 \%$ over initial copepod samples (Table 2). C. hamatus consumed an average of $32 \%$ mean body carbon $\mathrm{d}^{-1}$ when grazing toxic $A$. fundyense GTCA. 28 , with no significant difference in body carbon between initial and experimental copepods on that diet (Table 2). Copepods examined after experiments were apparently

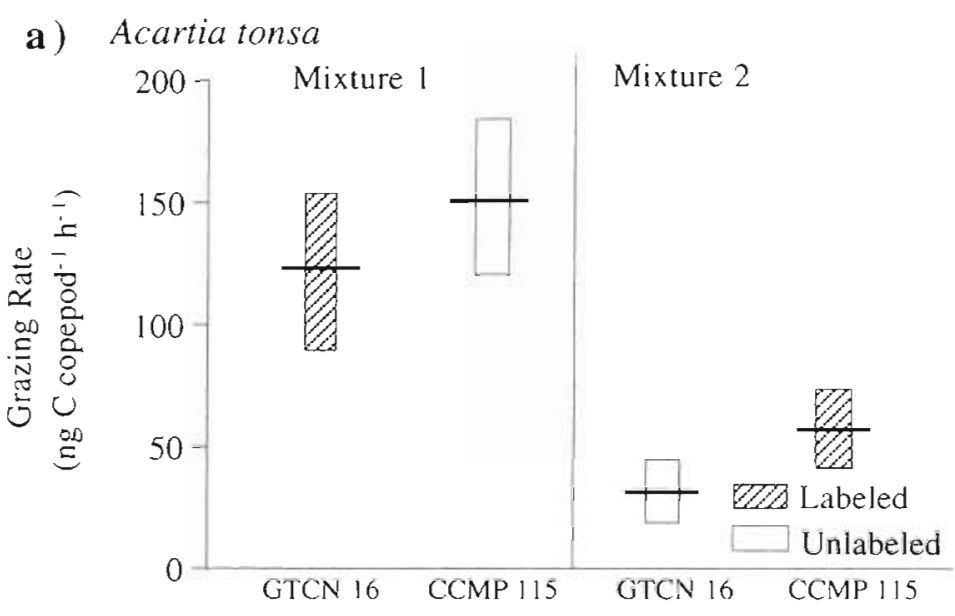

b) Eurytemora herdmani

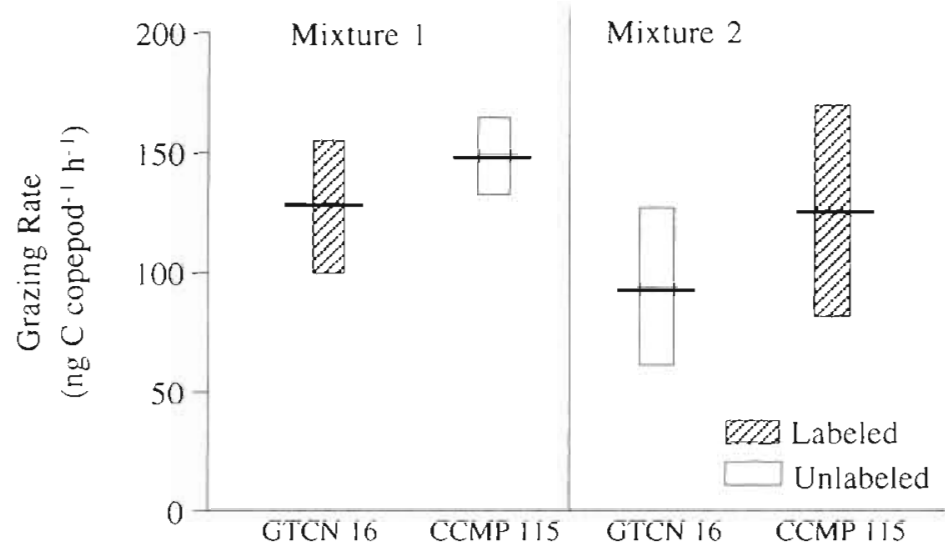

Fig. 4. (a) Acartia tonsa and (b) Eurytemora herdmani grazing rates in mixtures of 2 functionally non-toxic clones of Alexandrium tamarense, CCMP 115 and GTCN 16. Central bars denote mean rates, and boxes indicate 1 standard deviation. Although individual grazing rates and total carbon consumed were variable, there were no significant differences between grazing rates in any mixture treatment, for either copepod species

unaffected in either treatment, being equally active and with food in the guts in both cases. Despite the lack of observable impairment, consumption of the toxic GTCA 28 clone was significantly lower than the non-toxic CCMP 115 clone (Fig. 8), indicating a lack of either ability or willingness to consume a normal daily ration when toxic Alexandrium spp. cells are the only available food.

Unlike the other copepod species, Eurytemora herdmani did not exhibit significantly different grazing rates on monoculture diets of non-toxic Alexandrium tamarense CCMP 115 or toxic $A$. fundyense GTCA 28 (Fig. 8). The average percent mean body carbon consumed per day was $76 \%$ for a diet of $A$. tamarense CCMP 115, with a significant $(\mathrm{p}<0.05)$ carbon gain of $14 \%$ over initial samples (Table 2). On a diet of toxic $A$. 

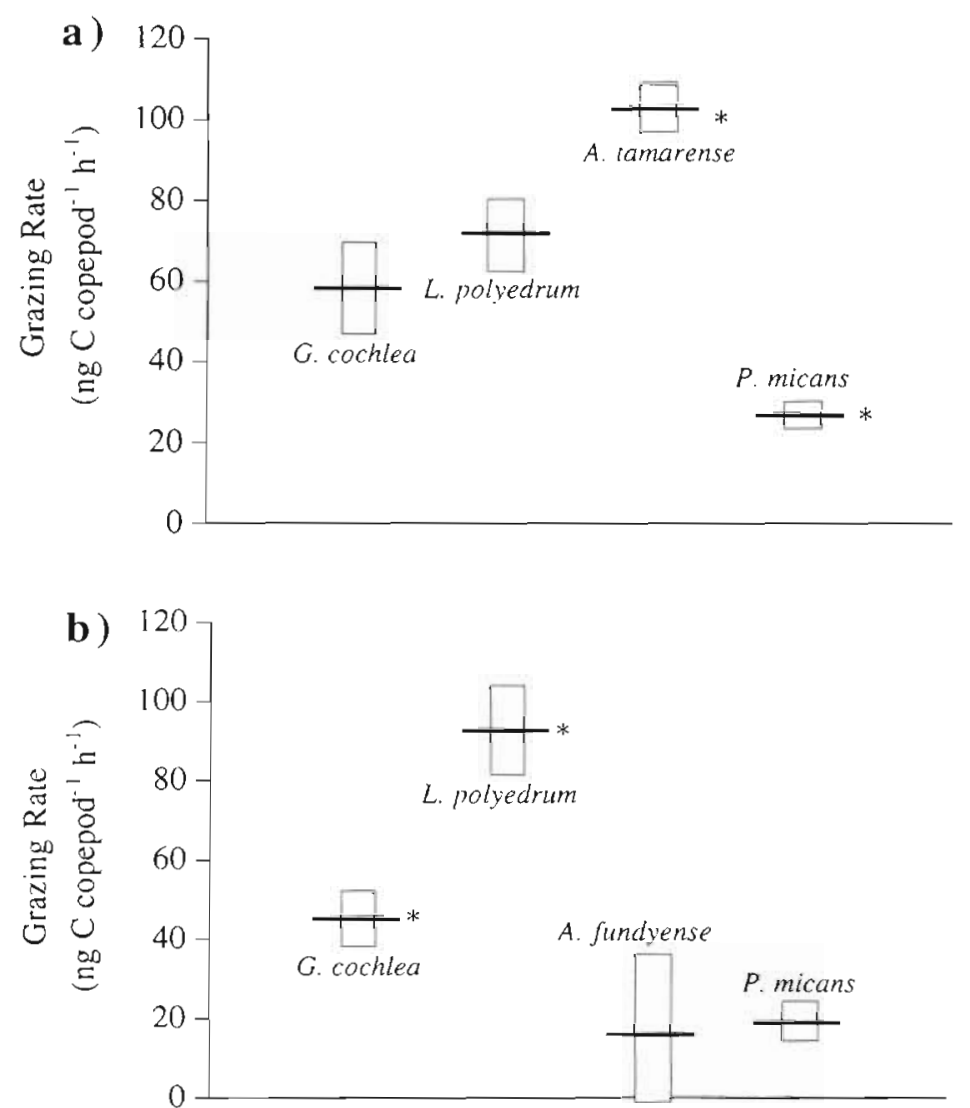

Fig. 5. Acartia tonsa grazing rates on mixtures of 4 species of dinoflagellates. Central bars denote mean rates, and boxes indicate 1 standard deviation. (a) In mixtures containing non-toxic Alexandrium tamarense CCMP 115, the CCMP 115 clone was consumed in preference to all other particles. (b) In the second treatment containing toxic $A$. fundyense GTCA 28, the Alexandrium clone was consumed at much lower rates, and Lingulodinium polyedrum and Gonyaulax cochlea were consumed at significantly higher rates than other species. *Significant difference $p<0.05$ in grazing rates from other dinoflagellate species

\section{DISCUSSION}

\section{Selection among Alexandrium spp. on the basis oi PSP toxin content}

The results of this study strongly suggest that selective grazing by omnivorous copepods, on the basis of PSP toxin content, is not only possible, but it is also likely to govern grazing response before physiological effects would cause impairment of grazing processes. This conclusion contrasts with a number of pioneering studies which suggested a physio- fundyense GTCA 28,63\% of total body carbon was consumed, and there was no significant difference in body carbon between initial and experimental copepods (Table 2). Mean grazing rates were not significantly different between the 2 treatments. Furthermore, in both treatments, copepods observed after the experiment showed no signs of impairment, and were equally active and healthy, with food in the guts and production of eggs observed in both treatments.

Fig. 6. Centropages hamatus grazing rates on mixtures of 4 species of dinoflagellates. Central bars denote mean rates, and boxes indicate 1 standard deviation. (a) As with Acartia tonsa, Alexandrium tamarense CCMP 115 was consumed in preference to all other species. (b) In the treatment containing toxic A. fundyense GTCA 28, grazing rates on Alexandrium were half of what they were in the first treatment, and rates on Gonyaulax cochlea and Lingulodinium polyedrum increased. grazing rates on $A$. fundyense and Prorocentrum micans were significantly lower than on the former species. *Significant difference $p<0.05$ in grazing rates from other dinoflagellate species
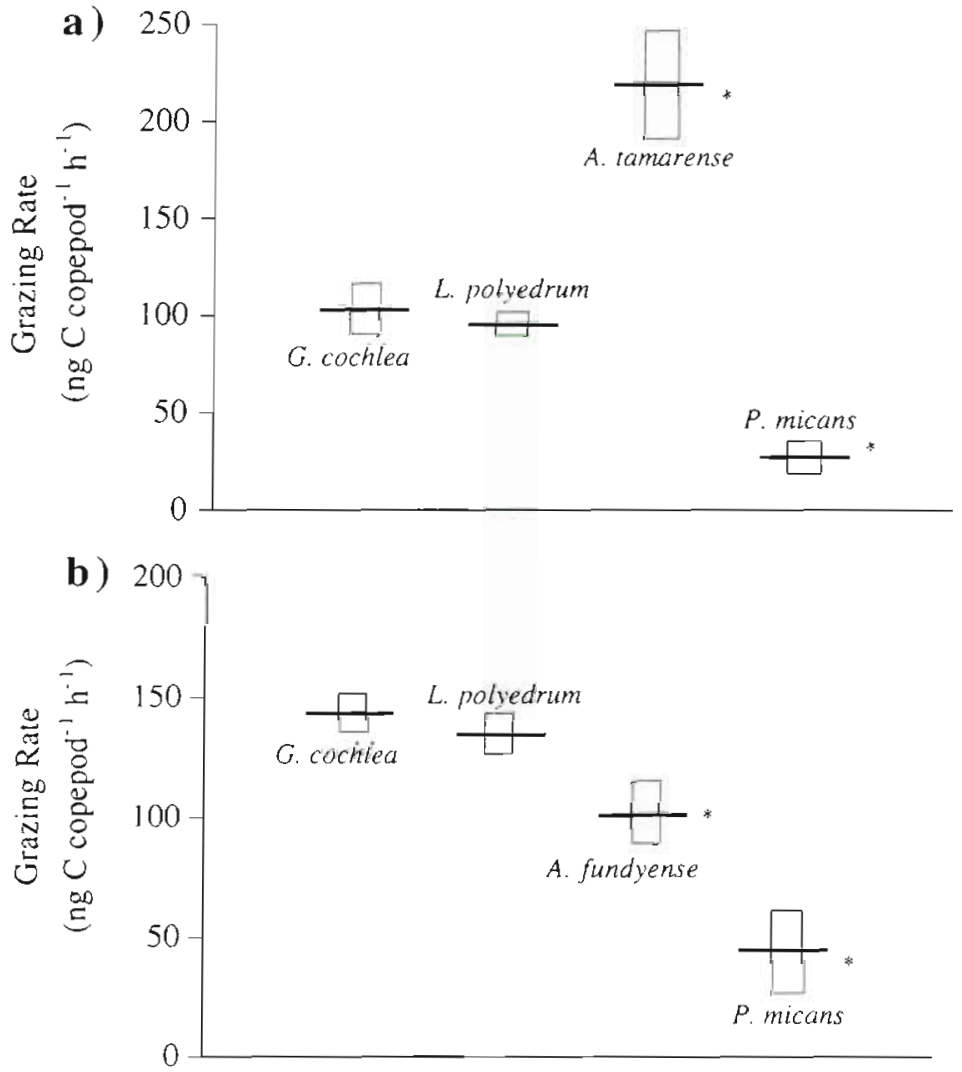

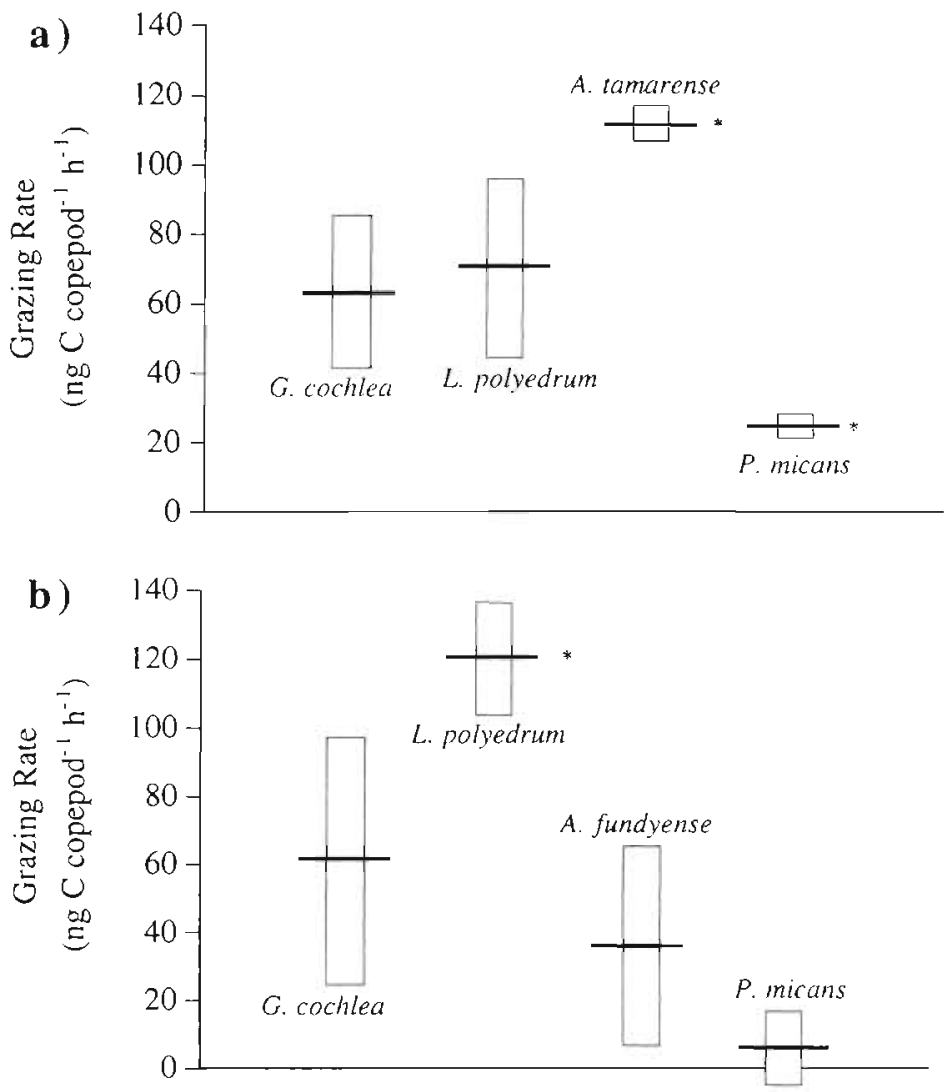

Fig. 7. Eurytemora herdmani grazing rates on mixtures of 4 species of dinoflagellates. Central bars denote mean rates, and boxes indicate 1 standard deviation. (a) Alexandrium tamarense was grazed at significantly higher rates than other species, while Prorocentrum micans was grazed at lower rates than all other species. (b) Grazing rates on $A$. fundyense were less than half of those on A. tamarense CCMP 115, while rates on Lingulodinium polyedrum increased and were significantly higher than rates on any other species. *Significant difference $\mathrm{p}<$ 0.05 in grazing rates from other dinoflagellate species logical basis for observed reduced consumption or rejection of such phytoplankton. Among the first to address the question of the mechanism of zooplankton grazing response were Ives $(1985,1987)$ and Huntley et al. (1986), who concluded that ingestion and subsequent physiological impairment caused rejection or avoidance of certain dinoflagellates, including Alexandrium spp. Uye \& Takamatsu (1990) tested several species of 'red tide' flagellates (not Alexandrium spp.) as food for copepods, and determined that intracellular chemicals caused feeding inhibition in some instances. These studies concluded that particle rejection did not take place prior to ingestion, and thus was not a result of chemosensory recognition of potential feeding deterrents present in certain phytoplankton. Huntley et al. (1986) and Ives (1987) concluded that toxins or feeding deterrents, including those produced by Alexandrium spp., may produce effects through the actual disabling of coordinated feeding appendage movement in copepods, rendering the grazer incapable of feeding. Uye \& Takamatsu (1990) speculated that trial-anderror consumption of harmful phytoplankton may allow grazers to learn which species should be avoided, after suffering impairment or recognizing unpalatable intracellular substances. Sykes (1991) lent support to this hypothesis. He found that, although Calanus pacificus could not recognize noxious Gonyaulax grindleyi (= Protoceratium reticulatum) prior to ingestion (and thus selectively avoid initial consumption), C. pacificus could

Table 2. Results from copepod carbon consumption experiments. The first column indicates copepod species, followed by the sample indicating which clone was grazed by copepods (or initial sample). Adjacent columns indicate the mean carbon copepod ${ }^{-1}$ measured by CHN analysis, carbon ingested copepod ${ }^{-1}$ calculated from grazing rates, the percentage of initial body carbon ingested $\mathrm{d}^{-1}$, and the total change in body carbon over $24 \mathrm{~h}$, expressed in $\mu \mathrm{g}$ and as a percentage of initial body carbon ("significant differences)

\begin{tabular}{|c|c|c|c|c|c|}
\hline Copepod sp. & $\begin{array}{l}\text { Sample/clone } \\
\text { grazed }\end{array}$ & $\begin{array}{c}\text { Carbon } \\
\left(\mu \text { copepod }^{-1}\right)\end{array}$ & $\begin{array}{c}\text { Carbon ingested } \\
\left(\mu \mathrm{g} C \text { copepod }{ }^{-1} h^{-1}\right)\end{array}$ & $\begin{array}{l}\% \text { body carbon } \\
\text { ingested } \mathrm{d}^{-1}\end{array}$ & $\begin{array}{c}\text { Change in body carbon } \\
\text { ( } \mu \text { g, \% initial } \\
\text { body carbon) }\end{array}$ \\
\hline Acartia tonsa & $\begin{array}{l}\text { Initial } \\
\text { CCMP } 115 \\
\text { GTCA } 28\end{array}$ & $\begin{array}{l}4.18 \pm 0.12 \\
4.93 \pm 0.04 \\
3.02 \pm 0.29\end{array}$ & $\begin{array}{c}- \\
0.37 \pm 0.03 \\
0.09 \pm 0.01\end{array}$ & $\begin{array}{c}- \\
196 \pm 15 \\
61 \pm 6\end{array}$ & $\begin{array}{c}- \\
+0.75,+18 \% \\
-1.16,-28 \%\end{array}$ \\
\hline Centropages hamatus & $\begin{array}{l}\text { Initial } \\
\text { CCMP } 115 \\
\text { GTCA } 28\end{array}$ & $\begin{array}{r}9.91 \pm 0.76 \\
12.25 \pm 0.72 \\
10.48 \pm 1.39\end{array}$ & $\begin{array}{c}- \\
0.22 \pm 0.03 \\
0.14 \pm 0.02\end{array}$ & $\begin{array}{c}- \\
47 \pm 7 \\
32 \pm 4\end{array}$ & $\begin{array}{l}- \\
+2.34,+24 \% \\
+0.57,+6 \%\end{array}$ \\
\hline Eurytemora herdmani & $\begin{array}{l}\text { Initial } \\
\text { CCMP } 115 \\
\text { GTCA } 28\end{array}$ & $\begin{array}{l}7.47 \pm 0.42 \\
8.55 \pm 0.47 \\
7.16 \pm 0.29\end{array}$ & $\begin{array}{c}- \\
0.25 \pm 0.06 \\
0.19 \pm 0.02\end{array}$ & $\begin{array}{l}\quad- \\
76 \pm 18 \\
63 \pm 7\end{array}$ & $\begin{array}{l}- \\
+1.08,+14 \% \\
-0.31,-4 \%\end{array}$ \\
\hline
\end{tabular}




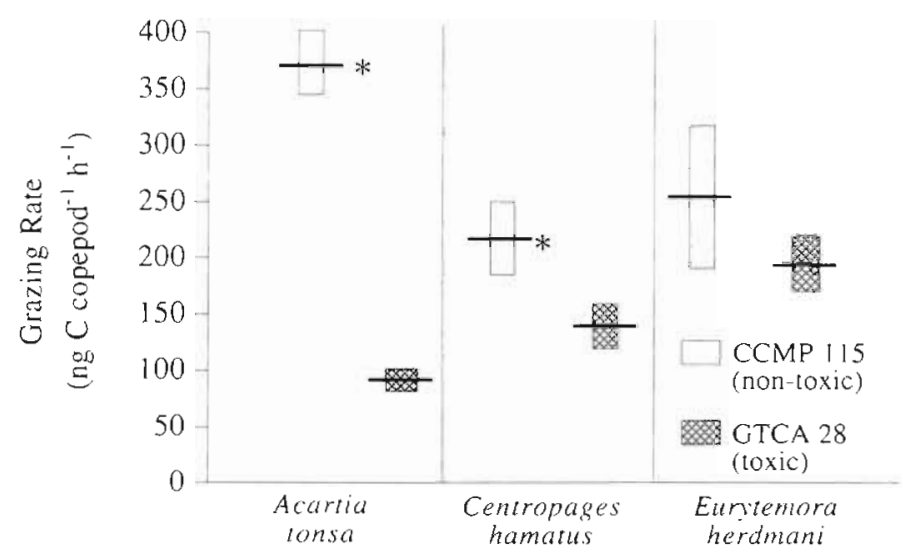

Fig. 8. Acartia tonsa, Centropages hamatus, and Eurytemora herdmani grazing rates on monocultures of either Alexandrium tamarense CCMP 115 or A. fundyense GTCA 28. Central bars are mean values, boxes indicate 1 standard deviation. *Significant differences. Both A. tonsa and C. hamatus demonstrated significantly higher grazing rates on monocultures of $A$. tamarense CCMP 115 than on $A$. fundyense GTCA $28(\mathrm{p}<0.001, \mathrm{p}=0.02$, respectively). $E$. herdmani grazed either monoculture at roughly equal rates (no significant difference, $p=0.2$ )

'remember' G. grindleyi from initial grazing trials and avoid subsequent ingestion upon re-exposure, but that this memory lasted only about $12 \mathrm{~h}$.

Recent experimental work has suggested that copepods do not need to consume harmful phytoplankton to the point of impairment to recognize and avoid potentially toxic cells, or distinguish such cells from palatable alternatives in mixtures. DeMott \& Moxter (1991) showed that a freshwater copepod (Diaptomus birgel) ingested the non-toxic cyanobacteria Oscillatoria tenuis (non-planktonic), while rejecting toxic (planktonic) $O$. rubescens or $O$. agardhii (which produce presumably toxic polypeptides) in mixtures of the species. Working with Alexandrium spp., Turriff et al. (1995) found that Calanus finmarchicus preferred the nontoxic, smaller diatom Thalassiosira weisflogii in mixtures with toxic $A$. excavatum, but non-toxic $A$. tamarense clone PLY 173 was grazed in preference to $T$. weisflogii in mixtures. In these experiments the prey available could easily be distinguished by size, cell abundance, and capture method, but the results certainly suggest that toxicity could be recognized and used by the copepods as a basis of rejection. The results do not however conclusively demonstrate that copepods could 'taste' PSP toxins, as it was possible (and the authors suggested) that trial-and-error consumption, with subsequent inimical effects, allowed the copepods to learn to recognize the unpalatable toxic species and avoid further grazing Teegarden \& Cembella (1996) found selection by grazing copepods in mixtures of toxic Alexandrium spp. and the non- toxic dinoflagellate Lingulodinium polyedrum, present in equal numbers. Although the prey used in that study were of similar size and equal concentration, the 2 cell types could probably be distinguished by the copepods via mechano- and chemoreceptors. In any case toxin content did not appear to be the principal factor governing selection, as a low toxicity $A$. tamarense clone was grazed in preference to $L$. polyedrum by one of the copepod species tested.

The results presented here strongly suggest that the copepods tested could recognize and reject toxic cells prior to ingestion, by chemosensory means. The 2 Alexandrium spp. clones used, considered by many to be conspecific, are virtually identical in all respects save toxin content, and could not be distinguished by mechanosensory abilities of the copepods (i.e. the copepods could not 'learn' to distinguish one cell type from another based on mechanical cues). In a mixture of such identical cell types, the only plausible explanation for the observed preference for nontoxic cells over toxic cells is that grazers could capture cells, use chemosensors to assess palatability, and reject less palatable cells, in this case cells producing PSP toxins. Since all dinoflagellates used were in exponential growth, culture age and physiological state should not have affected palatability. Furthermore the clear preference for non-toxic over toxic Alexandrium spp. demonstrated on several different experimental dates, and across 3 species of calanoid copepods, reinforces the conclusion that PSP toxin content is the factor affecting palatability. In experiments with 2 functionally non-toxic Alexandrium spp. dinoflagellates (Fig. 4) there was no significant difference in grazing rates, i.e. no grazing preference. All of these results lead to the following conclusions: (1) the copepods examined here can recognize Alexandrium spp. cells containing PSP toxins by chemosensory means, (2) if all else is equal PSP toxins render cells less palatable, (3) when such copepods are grazing in suspensions of more than 1 cell type, as would be the case in most natural environments, grazing of Alexandrium spp. dinoflagellates is governed by behavioral selection of prey, not physiological impairment due to ingested toxins.

One aspect of the results seems troubling; if toxic Alexandrium spp. cells are less palatable, why were they consumed in any quantity in all of the selection experiments? Could this be explained as a trade-off between the increased handling time involved in selection, and the apparent susceptibility to PSP toxins of each of the copepod species examined? Acartia tonsa is intolerant of PSP toxins (as seen in the strong impairment suffered in the monoculture grazing experiment), 
Centropages hamatus is more tolerant, but still will not consume monocultures of toxic cells at the same rate as non-toxic cells, and Eurytemora herdmani is moderately tolerant, showing no significant difference in grazing rates on toxic or non-toxic monoculture diets. In the selection experiments reported here, A. tonsa demonstrated very strong avoidance of toxic Alexandrium spp., C. hamatus avoided toxic cells to a lesser degree, and $E$. herdmani, while capable of avoiding toxic cells (Fig. 3b), was not constrained to do so (Fig. 3a). Physiological impairment was not observed in any of the selection experiments, and thus it is unlikely that ingestion of toxic cells by each of the 3 copepod species was sufficient to affect grazing processes. Since each Alexandrium spp. clone was present in equal, moderately high concentrations $\left(200{\text { cells } \mathrm{ml}^{-1}}^{-1}\right.$ each), it is likely that copepods consumed toxic cells in proportion to their ability to tolerate PSP toxins.

Lehman (1976) presented one of the first models of optimal foraging for selective 'filter feeders' such as copepods. In this and subsequent models, handling time was assumed to be negligible, and gut residence or evacuation was considered to be the principal time constraint. Such models further predict that selective feeding would be most noticeable when food concentrations are high, but that grazers would be less selective at lower food concentrations. If a copepod species such as Acartia tonsa (which is intolerant of PSP toxins) must practice selective grazing, but has ample alternate food, then this food should be consumed at rates limited only by digestive capacity. Yet individual $A$. tonsa consumed on average $4.7 \mu \mathrm{g}$ (estimated $105 \%$ body carbon) $\mathrm{d}^{-t}$ in selection experiments (Fig. 1), while in a monoculture of non-toxic Alexandrium tamarense CCMP 115 each $A$. tonsa consumed an average of $8.88 \mu \mathrm{g}$ or $196 \%$ body carbon $\mathrm{d}^{-1}$ (Table 2 ). Clearly the copepods from the selection experiments were not maximizing their daily intake. The very low number of toxic cells ingested argues against a physiological basis for this result; at the same time, it is difficult to imagine that the grazing rates, which correspond to less than 100 cells copepod ${ }^{-1} \mathrm{~h}^{-1}$, were limited by handling time. At this time there is not sufficient evidence to rule out the cost of handling as a factor that may affect grazing rates in mixtures containing high concentrations of toxic cells

On the other hand, Eurytemora herdmani consumed equivalent daily rations in virtually all of the experiments in this study (60 to $80 \%$ body carbon $\mathrm{d}^{-1}$ ), whether it practiced selection or not, even in monocultures of toxic Alexandrium spp. Addressing selective grazing mechanisms of freshwater and marine zooplankton in the context of optimal foraging models, DeMott (1990) remarked that 'calanoid copepods show strong, invariant selection against toxic algae,' arguing that abstinence is still preferable to consumption of inimical food items. The fact that $E$, herdmani would consume significant quantities of toxic cells when nontoxic cells were abundant and food was not limiting, and the species is apparently capable of toxin detection and selection by chemosensory means, raises interesting questions. It is likely that this species has developed a tolerance to PSP toxins, similar to that postulated for certain cladocera and cyanobacterial toxins (DeMott \& Moxter 1991). Are both Acartia tonsa and E. herdmani practicing optimal foraging? Not all copepod species must reject toxic cells, nor do species capable of selection necessarily obtain a maximal rate of energy gain when alternate food is abundant. It is possible by using ad hoc arguments to conclude that these results may be recognized as optimal foraging within the physiological constraints of the individual species, but the utility of optimal foraging models to predict copepod behavior in the presence of toxic cells is limited. One must conclude that grazer response to toxic prey will vary among species, and that grazing impact on blooms of Alexandrium spp. will depend on the composition of the zooplankton community.

\section{Mixed dinoflagellate species grazing experiments}

The experiments with several species of dinoflagellate prey performed in this study provide perhaps the best illustration of the difference in palatability between toxic and non-toxic Alexandrium spp. One of the most striking results from these experiments is the preference of all 3 copepod species for non-toxic $A$. tamarense CCMP 115 over other non-toxic and apparently palatable and nutritious dinoflagellate species (Figs. 5a, 6a \& 7a). Such consistent results strongly suggest that non-toxic Alexandrium spp. are perceived as high-quality food, and may be selectively consumed by zooplankton relative to other available prey. Dinoflagellates typically have high nitrogen content and large cytoplasmic volume relative to many other phytoplankton types (Hitchcock 1982), and zooplankton preference for dinoflagellates over other phytoplankton has been suggested from both laboratory and field work (e.g. Morey-Gaines 1980, Kleppel et al. 1991). Turriff et al. (1995) found selective grazing by Calanus finmarchicus on non-toxic $A$. tamarense over the diatom Thalassiosira weisflogii, and Teegarden \& Cembella (1996) observed preference for A. tamarense over Lingulodinium polyedrum by the copepod Eurytemora herdmani, despite the presence of a low level of toxin in the $A$. tamarense clone. The results of the present study and those mentioned above suggest that non-toxic or low-toxicity Alexandrium spp. are highly susceptible to grazing losses. 
Substitution of toxic Alexandrium fundyense GTCA 28 in the second mixed-species treatments resulted in significant reductions in grazing rates on that clone compared to non-toxic A. tamarense CCMP 115 for all 3 copepod species, underscoring the fact that the presence of PSP toxins renders Alexandrium spp. less palatable to grazers. Nevertheless the toxic clone was not universally rejected, nor was it necessarily consumed at much lower rates than alternative prey species. Acartia tonsa grazed toxic A. fundyense GTCA 28 at significantly lower rates than most other dinoflagellate species (except Prorocentrum micans, Fig, 5b), consistent with the apparent inability of $A$. tonsa to tolerate PSP toxin ingestion (see monoculture experiment discussion). Centropages hamatus grazed toxic A. fundyense GTCA 28 at a significantly higher rate than $P$. micans, and Eurytemora herdmani grazed $A$. fundyense GTCA 28 at rates comparable to Gonyaulax cochlea and $P$. micans (Figs. $6 \mathrm{~b} \& 7 \mathrm{~b}$ ). Thus for these 2 copepod species, consumption of the toxic clone was not prevented or even strongly inhibited, but merely reduced to a level comparable to those on alternate dinoflagellate species. One may conclude from these results that the presence of PSP toxins in the $A$. fundyense GTCA 28 clone confers the definite advantage of reducing that dinoflagellate's palatability or desirability compared to Alexandrium spp. without PSP toxins, but does not cause them to be avoided or selected against by all grazer species.

Reduction of grazing pressure on Alexandrium spp. due to the presence of toxin often resulted in increased grazing pressure on alternate species of dinoflagellates in mixtures. If selective grazing is practiced in natural environments, copepods may exert a greater grazing pressure on alternate phytoplankton species, essentially competitors of Alexandrium spp., in order to maintain daily rations. Centropages hamatus and Eurytemora herdmani maintained equivalent rations in both treatments. These 2 species of copepods were therefore flexible enough to switch particle preference in the presence of toxic prey to ensure consumption of a sufficient ration. Only Acartia tonsa failed to maintain equivalent carbon rations in both treatments. In the first (non-toxic) treatment, $39 \%$ of A. tonsa total carbon ration came from non-toxic $A$. tamarense CCMP 115, significantly more than any other dinoflagellate species. Although $A$. tonsa switched grazing preference to Lingulodinium polyedrum (54\% of the total ration) in the second (toxic) treatment, consumption of all species was not sufficient to equal total carbon consumed in the first treatment. The reason for this discrepancy is not clear at this time; the copepods were healthy and active at the end of experiments, so it is unlikely that physiological impairment inhibited grazing activity. It is possible that the increased costs of handling and selective ingestion in the second treatment were sufficient to depress overall carbon consumption, but without actual measurements of energetic expenditures it is impossible to suggest this with confidence. It is also possible that the Gonyaulax cochlea and Prorocentrum micans were not sufficiently palatable to $A$. tonsa, and without the preferred nontoxic $A$. tamarense, $A$. tonsa was not induced to increase consumption of those alternate species to make up for reduced consumption of Alexandrium spp.

\section{Monoculture grazing experiments}

When Acartia tonsa, Centropages hamatus and Eurytemora herdmani were offered monocultures of Alexandrium spp. as an exclusive diet, the differential susceptibility of the copepod species to the effects of PSP toxins was apparent. A. tonsa and C. hamatus did not maintain equivalent carbon consumption rates between the 2 treatments. The greatest discrepancy occurred in $A$. tonsa grazing trials. A. tonsa fed nontoxic $A$. tamarense CCMP 115 grazed at a very high rate, $>196 \%$ body $\mathrm{C} \mathrm{d}^{-1}$ (Table 2 ), and copepods were healthy and active, and had produced eggs. Copepods from the concurrent treatment fed a monoculture diet of toxic $A$. fundyense GTCA 28 consumed only $61 \%$ body $\mathrm{C} \mathrm{d}^{-1}$, and were clearly impaired; copepods were motionless at the bottom of the experimental containers, and displayed no response upon examination, although most were still living (mortality $<10 \%$ ). A. tonsa is a species that relies on regular consumption of food, and does not tolerate starvation (Dagg 1977, Durbin et al. 1983). This requirement may have overridden a behavioral aversion to consumption of toxic Alexandrium spp., and induced sufficient grazing to effect physiological incapacitation when no other food was available. The fact that severe impairment was apparent at a moderate rate of consumption of toxic $A$. fundyense GTCA 28 indicates that this species has a low tolerance for ingestion of PSP toxins, and if selective grazing is not allowed, as in the very unusual case of a virtually monospecific bloom of Alexandrium sp., grazing (and thus growth and production) of $A$. tonsa may be inhibited by physiological impairment.

Centropages hamatus also displayed significantly different grazing rates between monoculture Alexandrium spp. diets. Rates of consumption were 47 and $33 \%$ of body carbon $\mathrm{d}^{-1}$ for non-toxic $A$. tamarense CCMP 115 and toxic A. fundyense GTCA 28 respectively (Table 2). Consumption of toxic cells was moderately high, yet did not result in any observable impairment of copepods, and food was observed in the guts of 
copepods from that treatment. This species apparently can tolerate moderate consumption of toxic cells, and is not likely to ever suffer impairment in natural situations. The reduced consumption by $C$. hamatus of toxic compared to non-toxic Alexandrium spp. cells in monocultures appears to reflect a behavioral bias against toxic prey. Although maximum daily rations were not attained on toxic Alexandrium spp. cells alone, severe starvation is unlikely, since in this experiment $C$. hamatus maintained average body carbon over $24 \mathrm{~h}$ (Table 2).

Eurytemora herdmani did not exhibit significant differences in grazing rates on the 2 Alexandrium spp. monoculture diets. This is consistent with the conclusion that $E$. herdmani is generally tolerant of PSP toxin consumption, augmented by the fact that impairment of this species was never observed in any of the experiments conducted in this study. Such tolerance probably allows $E$. herdmani to obtain its daily ration when no other food is available. Significant growth did occur in the non-toxic treatment (Table 2), but there was no significant difference between initial copepod samples and copepods which had fed on toxic $A$. fundyense GTCA 28. It is not known at this time whether ingestion of toxin has any effects on the copepod's ability to assimilate food, or why there should be a difference in growth between the 2 diets when no difference in grazing rates was discerned. Possible effects of long term exposure to PSP toxins on physiology and production are also not known at this time.

\section{On the function of PSP toxins}

The idea that PSP toxin production in Alexandrium spp. is an adaptation for grazer defense, and that defense is the function (sensu Williams 1966) of PSP toxins, has not been universally accepted, often because of the failure of PSP toxins to provide perfect defense, e.g. as demonstrated here with the copepod Eurytemora herdmani. Another problem stems from earlier arguments that PSP toxins could not be detected prior to ingestion, and that effects were physiological (Ives 1985, 1987, Huntley et al. 1986). If defense cannot be effected prior to ingestion, then the only benefit of the chemical deterrent would be for the species, when some cells in a population are saved by the sacrifice of other individuals. Such a case suggests natural selection at the group level, which most biologists are unwilling to support as powerful enough for development of an adaptation (Williams 1966). Numerous 'effects' on grazers have been attributed to PSP toxins (see Turner \& Tester 1997 and references therein), including reduced growth and inhibited production of future generations, but unless a defense can be discerned which benefits individual Alexandrium spp. cells, it is difficult to argue that the 'function' of PSP toxins in Alexandrium spp. is to provide defense against grazers.

The results of the experiments reported here strongly suggest that cells containing PSP toxins can be discerned by grazers prior to ingestion. The results of the mixed dinoflagellate species experiments in particular demonstrate that non-toxic Alexandrium spp. cells are highly susceptible to grazing losses, while the presence of toxin in Alexandrium spp. renders such cells much less palatable; even to grazers such as Eurytemora herdmani that are apparently tolerant of PSP toxins. The selection experiments further demonstrate that cells which 'taste bad' can be rejected without mortal damage. Shaw et al. (1997), in a study combining experimental and modeling analyses of copepod response to purified toxins (including PSP toxins), argued convincingly that PSP toxins act as deterrents, which can be recognized by chemosensors, rather than as toxins which induce physiological impairment or mortality. Haney et al. (1995) concluded that the cladoceran Daphnia carinata responded to purified saxitoxin in a manner consistent with chemosensory stimulation, not physiological inhibition. Yamamori et al. (1988) have postulated the existence of chemosensors in fish which can 'taste' PSP toxins. One may conclude from all of these results that PSP toxins are distasteful, and that a good number of marine species are probably capable of sensing and avoiding prey containing PSP toxins.

This defense is not infallible, since toxic Alexandrium spp. cells may be consumed at moderately high rates, as seen in this study with Eurytemora herdmani and (to some extent) Centropages hamatus. But a perfect defense is not required for the evolution of a chemical deterrent. The possibility that some zooplankton species (e.g. E. herdmani) may have developed tolerance to toxin ingestion does not alter the fact that nontoxic Alexandrium spp. cells were consistently preferred in the diet relative to toxic Alexandrium spp. cells. Across all experiments and all copepod species examined here, toxic Alexandrium spp. cells enjoyed a distinct advantage over non-toxic Alexandrium spp. cells in the presence of selective grazers. If a toxic Alexandrium spp. cell is more likely to avoid being consumed than a non-toxic Alexandrium spp. cell, and it can be rejected without suffering mortal damage, it therefore has a greater probability of surviving long enough to reproduce and proliferate. Thus natural selection at the individual level should favor the production of PSP toxins by Alexandrium spp. in many environments, and it is reasonable to consider PSP toxin production an evolved adaptation for grazer deterrence. 
Acknowledgements. The assistance of Dr Allan Cembella and Ms Nancy Lewis, IMB-NRC, Halifax, NS, for toxin analysis of culture samples, is gratefully acknowledged. Dr Edward G. Durbin provided laboratory facilities, encouragement, and financial support in the form of an assistantship during a portion of the work. Some Alexandrium spp. clones were generously provided by the laboratory of Dr Donald M. Anderson. and other species through the courtesy of Dr Paul E. Hargraves. I thank E. G. Durbin, A. D. Cembella and 3 anonymous reviewers for providing critical reviews of the manuscript. This study was also funded in part by NSF grant OCE-9726261.

\section{LITERATURE CITED}

Balech E (1990) A short diagnostic description of Alexandrium. In: Granéli E, Sundström B, Edler L, Anderson DM (eds) Toxic marine phytoplankton. Elsevier, New York, $p 77$

Cody RP, Smith JK (1991) Applied statistics and the SAS ${ }^{\otimes}$ programming language. North-Holland, New York

Dagg M (1977) Some effects of patchy food environments on copepods. Limnol Oceanogr 22:99-107

DeMott WR (1990) Retention efficiency, perceptual bias, and active choice as mechanisms of food selection by suspension-feeding zooplankton. In: Hughes RN (ed) Behayioural mechanisms of food selection, NATO ASI Series, Vol G20. Springer-Verlag, Berlin, p 569-594

DeMott WR, Moxter F (1991) Foraging on cyanobacteria by copepods: responses to chemical defenses and resource abundance. Ecology 72:1820-1834

Durbin EG, Durbin AG, Smayda TJ, Verity PG (1983) Food limitation of production by adult Acartia tonsa in Narragansett Bay, Rhode Island. Limnol Oceanogr 28: 1199-1213

Frost BW (1972) Effects of size and concentration of food particles on the feeding behavior of the marine planktonic copepod Calanus pacificus. Limnol Oceanogr 17 : $805-815$

Geraci JR, Anderson DM, Timperi RJ, St Aubin DJ, Early GA, Prescott JH, Mayo CA (1989) Humpback whales (Megaptera novaeangliae) fatally poisoned by dinoflagellate toxin. Can J Fish Aquat Sci 46:1895-1898

Guillard RRL (1975) Culture of marine phytoplankton for feeding marine invertebrates. In: Smith WL, Chaney $\mathrm{MH}$ (eds) Culture of marine invertebrate animals. Plenum, New York, p 29-60

Haney JF, Sasner JJ, Ikawa M (1995) Effects of products released by Aphanizomenon flos-aquae and purified saxitoxin on the movements of Daphnia carinata feeding appendages. Limnol Oceanogr 40:263-272

Hitchcock GL (1982) A comparative study of the size-dependent organic composition of marine diatoms and dinoflagellates. J Plankton Res 4:363-377

Huntley M, Sykes P, Rohan S, Marin V (1986) Chemicallymediated rejection of dinoflagellate prey by the copepods Calanus pacificus and Paracalanus parvus: mechanism, occurrence and significance. Mar Ecol Prog Ser 28: $105-120$

Ives JD (1985) The relationship between Gonyaulax tamarensis cell toxin levels and copepod ingestion rates. In: Anderson DM, White AW, Baden DG (eds) Toxic dinoflagellates Elsevier, New York, p 413-418

Ives JD (1987) Possible mechanisms underlying copepod grazing responses to levels of toxicity in red tide dinoflagellates. J Exp Mar Biol Ecol 112:131-145
Kleppel GS, Holliday DV, Pieper RE (1991) Trophic interactions between copepods and microplankton: A question about the role of diatoms. Limnol Oceanogr 36:172-178

Lehman JT (1976) The filter-feeder as an optimal forager, and the predicted shapes of feeding curves. Limnol Oceanogr 21:501-516

Morey-Gaines G (1980) The ecological role of dinoflagellate blooms in the Los Angeles-Long Beach Harbor. PhD dissertation, University of Southern California, Los Angeles

Shaw BA, Andersen RJ, Harrison PJ (1997) Feeding deterrent and toxicity effects of apo-fucoxanthinoids and phycotoxins on a marine copepod (Tigriopus californicus). Mar Biol 128:273-280

Shumway SE, Sherman-Caswell S, Hurst JW (1988) Paralytic shellfish poisoning in Maine: monitoring a monster. J Shellfish Res 7:643-652

Smayda T (1992) Global epidemic of noxious phytoplankton blooms and food chain consequences in large ecosystems. In: Sherman K, Alexander LM, Gold BD (eds) Food chains, yields, models, and management of large marine ecosystems. Westview Press, Boulder, p 275-307

Sykes PF (1991) Physiological-ecology and chemical-ecology of copepod-dinoflagellate interactions. PhD dissertation, University of California, San Diego

Teegarden GJ, Cembella AD (1996) Grazing of toxic dinoflagellates, Alexandrium spp., by adult copepods of coastal Maine: implications for the fate of paralytic shellfish toxins in marine food webs. J Exp Mar Biol Ecol 196:145-176

Turner JT, Anderson DM (1983) Zooplankton grazing during dinoflagellate blooms in a Cape Cod embayment, with observations of predation upon tintinnids by copepods. Mar Ecol 4:359-374

Turner JT, Tester PA (1997) Toxic marine phytoplankton, zooplankton grazers, and pelagic food webs. Limnol Oceanogr 42:1203-1214

Turriff N, Runge JA, Cembella AD (1995) Toxin accumulation and feeding behaviour of the planktonic copepod Calanus finmarchicus exposed to the red-tide dinoflagellate Alexandrium excavatum. Mar Biol 123:55-64

Uye S, Takamatsu K (1990) Feeding interactions between planktonic copepods and red-tide flagellates from Japanese coastal waters. Mar Ecol Prog Ser 59:97-107

Watras CJ, Garcon VC, Olson RJ, Chisholm SW, Anderson DM (1985) The effect of zooplankton grazing on estuarine blooms of the toxic dinoflagellate Gonyaulax tamarensis. J Plankton Res 7:891-908

White AW (1979) Dinoflagellate toxins in phytoplankton and zooplankton fractions during a bloom of Gonyaulax excavata. In: Taylor FJR, Seliger $\mathrm{HH}$ (eds) Toxic dinoflagellate blooms. Elsevier, New York, p 381-384

White AW (1980) Recurrence of kills of Atlantic herring (Clupea harengus harengus) caused by dinoflagellate toxins transferred through herbivorous zooplankton. Can J Fish Aquat Sci 37:2262-2265

White AW (1981) Marine zooplankton can accumulate and retain dinoflagellate toxins and cause fish kills. Limnol Oceanogr 26:103-109

Williams GC (1966) Adaptation and natural selection. Princeton University Press, Princeton

Yamamori K, Nakamura M, Matsui T, Hara TJ (1988) Gustatory responses to tetrodotoxin and saxitoxin in fish: a possible mechanism for avoiding marine toxins. Can J Fish Aquat Sci 45:2182-2186

Yentsch CM, Dale B, Hurst JW (1978) Coexistence of toxic and nontoxic dinoflagellates resembling Gonyaulax tamarensis in New England coastal waters (NW Atlantic). J Phycol 14:330-332 